Tropical Journal of Pharmaceutical Research June 2018; 17 (6): 1081-1086

ISSN: $1596-5996$ (print); 1596-9827 (electronic)

(c) Pharmacotherapy Group, Faculty of Pharmacy, University of Benin, Benin City, 300001 Nigeria.

Available online at http://www.tjpr.org

Original Research Article

http://dx.doi.org/10.4314/tjpr.v17i6.15

\title{
Inhibitory effects of methanol extracts of selected plants on the proliferation of two human melanoma cell lines
}

\author{
Alaa Fraihat ${ }^{1}$, Luma Alatrash ${ }^{2}$, Reem Abbasi ${ }^{1}$, Bashaer Abu-Irmaileh ${ }^{3}$, \\ Saja Hamed ${ }^{4}$, Mohammad Mohammad ${ }^{2}$, Eman Abu-Rish ${ }^{2}$, Yasser \\ Bustanji $i^{2,3^{*}}$ \\ ${ }^{1}$ Department of Associate Nursing in Al-Balqa Applied University, Ajloun, Jordan, ${ }^{2}$ School of Pharmacy, The University of \\ Jordan, Amman, Jordan, ${ }^{3}$ Hamdi Mango Center for Scientific Research, The University of Jordan, Amman, Jordan, ${ }^{4}$ Faculty of \\ Pharmaceutical Sciences, The Hashemite University. Al-Zarqa, Jordan \\ *For correspondence:: Email: bustanji@ju.edu.jo, Tel. +9625355000, Fax: +962 5300238
}

Revised accepted: 19 Mar 2018

\begin{abstract}
Purpose: To investigate the in vitro antiproliferative activity of methanol extracts of six plants regardless of their claimed ethnopharmacological application.

Methods: Methanol extracts of different parts of Glycyrrhiza glabra L. Licorice), Matricaria chamomilla L. (Chamomile), Salvia triloba L. (Sage), Rheum palmatum L. (Rhubarb), Trigonella foenum-graecum L (Fenugreek) and Sambucus ebulus L. (Dwarf Elder)were prepared. The antiproliferative effects of the extracts weretestedon two skin cancer melanoma cell lines namely A375.S2 (low tyrosinase expression) and WM 136.1A (high tyrosinase expression) using MTT assay. The IC50 values for the active extracts were determined against the two melanoma cell lines.

Results: The methanol extracts of G. glabra, M. chamomilla, S.triloba, R. palmatum inhibited the melanotic WM1361A proliferation in a dose-dependent manner revealing $I C_{50}$ values of 35.2, 25.2, 20.6, 17.8, $\mu \mathrm{g} / \mathrm{ml}$, respectively but not A375.S2 cell line. However, the extracts of T. foenum-graecum and S. ebulus did not exhibit any significant cytotoxic activity on both melanoma cell lines.

Conclusion: Methanol extracts of Licorice, Chamomile, Sage and Rhubarb have significant antiproliferative activity on WM1361A cell line; a representative human melanotic melanocyte tumor cell line. This renders these plants as potential sources of new lead compounds for the development of new drugs for melanoma cancer.
\end{abstract}

Keywords: Melanoma, Plant extract, tyrosinase, Licorice, Chamomile, Sage, Rhubarb, WM1361A.

\begin{abstract}
This is an Open Access article that uses a funding model which does not charge readers or their institutions for access and distributed under the terms of the Creative Commons Attribution License (http://creativecommons.org/licenses/by/4.0) and the Budapest Open Access Initiative (http://www.budapestopenaccessinitiative.org/read), which permit unrestricted use, distribution, and reproduction in any medium, provided the original work is properly credited.
\end{abstract}

Tropical Journal of Pharmaceutical Research is indexed by Science Citation Index (SciSearch), Scopus, International Pharmaceutical Abstract, Chemical Abstracts, Embase, Index Copernicus, EBSCO, African Index Medicus, JournalSeek, Journal Citation Reports/Science Edition, Directory of Open Access Journals (DOAJ), African Journal Online, Bioline International, Open-J-Gate and Pharmacy Abstracts 


\section{INTRODUCTION}

Discovery of new drugs or compounds with antineoplastic activity from natural sources have become popular among scientific communities, presenting new opportunities in the management of different types of cancer. The structural variety, cost effectiveness with their fewer side effects of these new compounds in comparison to their synthetic counterparts makes them much more preferable in cancer treatment.

Based on literature search, folk-lore use and investigational experiments, six popular plants (Table 1) that are widely distributed in the Mediterranean region and cultivated in Jordan have been reported to exhibit anticancer activity against one or more type of cancer cell line and possessed many medical benefits [1]

Sage (Salvia) species are greatly valued medicinal plants that are widely used in pharmaceutical products and traditional medicine. Aerial extract of Sage has been used in the relief of pain, protecting the body against oxidative stress and free radical damages [2] and also exhibited anti-angiogenic activity[3]. Salvia essential oils have also been reported to exhibit antibacterial [4, 5], anti-viral [6], and cytotoxic effects against some cancer cell lines including human larynx epidermoid carcinoma (HEp-2) [7] and breast adenocarcinoma (MCF7) [8].

Chamomile flowers have been used for centuries in the relief of inflammation [9] and colic spasms in young children. Cosmetically, it is used as a rinse for blonde hair. It is also used in topical preparation for the management of eczema and skin disorders [10]. Recently, it was reported that chamomile extracts can induce apoptosis in cancer cells but not in normal cells at similar doses [11].

Various beneficial effects of Fenugreek seeds extract have been reported these include antioxidant and anti-carcinogenic activities [12, 13]. The seeds contain several highly desirable biologically active compounds which are used in the food and pharmaceutical industries [14, 15].
Rhubarb roots extract has been associated with different medical activities such as laxative, astringent and antibacterial [16, 17]. Recent research has shown promising effect in possibly inhibiting angiogenesis, which may be implicated in its antitumor and anti-inflammatory activities [18]. Furthermore, the extract has also been shown to have inhibitory effects against the activity of mushroom tyrosinase [19].

Regardless of the world-wide intake of Licorice roots, their potential effects on endogenous substances and drugs have not been reported. It has been found that The licorice root extract can both improve the impaired function of liver and kidney and also has shown to have hypoglycemic activity in rats [20]. Also, it has an anti-inflammatory action that might inhibit the breakdown of cortisol produced by the body [21].Licorice roots extract has been implicated in skin whitening due to its tyrosinase inhibition activity [22].

Many traditional medicinal uses of Dwarf Elder fruits are known. These fruits are used in the treatment of burns, infectious wounds, eczema and rheumatism and also possesses antiinflammatory, antimicrobial, anti-neoplastic and antioxidant activities [23-25].

In spite of the numerous folkoric uses and the recorded anticancer orland antioxidant activities of Sage, Chamomile, Licorice, Fungreek, Rhubard and Dwarf Elder, little is known about their anti-proliferative effect against melanoma. Cancer being the second most common cause of death after cardiovascular and heart diseases in Jordan coupled with the use of traditional topical herbal preparationsas an acceptable safe and readily available choice of therapy for skin cancer in Jordan [26] have informed this study. The in vitroantiproliferative activities ofsixplant extracts on two melanoma cell lines that vary in the degree of tyrosinase enzyme expression were investigated. The two melanoma cell lines were a melanotic epithelial-like A375.S2 which shows low tyrosinase expression and the melanotic WM1361A cell line that is characterized with high tyrosinase expression [27].

Table 1: List of plants evaluated in this study

\begin{tabular}{llll}
\hline Plant Name & Family & Common Name & Part used \\
\hline Glycyrrhiza glabraL. & Fabaceae & Licorice & Root \\
Matricaria chamomillaL. & Asteraceae & Chamomile & Aerial part \\
Salvia triloba L. & Lamiacea & Sage & Aerial part \\
Rheum palmatum L. & Polygonaceae & Rhubarb & Roots \\
Trigonella foenum-graecum L. & Fabaceae & Fenugreek & Seeds \\
Sambucus ebulus L. & Caprifoliaceae & Dwarf Elder & Leaves and fruits \\
\hline
\end{tabular}




\section{EXPERIMENTAL}

\section{Plant extraction}

Plants were obtained from local market were identified by Kahled Tawaha (Professor of Pharmacognosy, School of Pharmacy, the University of Jordan). Voucher specimens (No. GLY-GL 2015,MAT-CA 2015,SA-TR 2015,RHPA 2015,TR-GR 2015,SA-EB 2015) for Licorice, Chamomile, Salvia, Rhubarb, Fenugreek and Dwarf Elder respectively have been deposited at the herbarium of the same institute.

For each plant, methanol extract was prepared by weighing $100 \mathrm{gm}$ of powdered dried plant, then soaking in $500 \mathrm{ml}$ of $96 \%$ methanol solution at room temperature for 7 days and then filtered. The filtrate was then evaporated to dryness using a rotary evaporator (Stuart, UK)and the resultant extracts were stored in dry and cool place until used [28].

\section{Plant extract preparation}

The extract residue (2 $\mathrm{mg}$ each) was dissolved in $10 \mathrm{ml}$ of RPMI 1640 medium with $10 \%$ heatinactivated fetal bovine serum (FBS) (Euroclone, Italy) to get a final concentration of $200 \mu \mathrm{g} / \mathrm{ml}$, and then was filtered using a syringe filter with $0.2 \mu \mathrm{m}$ pore size. The sterile plant solution with the concentration of $200 \mu \mathrm{g} / \mathrm{ml}$ was used as a stock solution for preparing further 5-fold dilutions with the concentrations of 6.25 to100 $\mu \mathrm{g} / \mathrm{ml}$ to determine their cytotoxic effects and screening their anticancer activities.

\section{Cell culture}

The two solid human melanocyte tumor cell lines; A375.S2 and WM1361A were cultured in RPMI1640 medium supplemented with $10 \%$ fetal bovine serum, $10 \mathrm{mM}$ HEPES buffer $(\mathrm{pH} 7.3)$, $2 \mathrm{mM}$ L-glutamine, $50 \mu \mathrm{g} / \mathrm{ml}$ gentamicin, 100U/ml penicillin, and $100 \mu \mathrm{g} / \mathrm{ml}$ streptomycin sulfate. The cultures were maintained at $5 \% \quad \mathrm{CO}_{2}$ in humid environment at $37 \stackrel{\circ}{\circ}$. Viable cell count was assessed using trypan blue dye exclusion method [28].

\section{Cytotoxicity and mtt cell viability assays}

Cytotoxicity of each plant extract was determined by MTT assay. Briefly, the cells were cultured in RPMI 1640 medium which was supplemented with $10 \%$ FBS in a humidified $5 \% \quad \mathrm{CO}_{2}$ atmosphere. Cells in their log growth phase were harvested using trypsin-EDTA solution (Euroclone, Italy), washed three times with PBS, and then suspended in $10 \mathrm{ml}$ of culture media with trypsin $0.25 \%$-EDTA $10 \mathrm{mM}$. The cell suspension was then centrifuged at $5000 \mathrm{rpm}$ for $10 \mathrm{~min}$ and the pellets were re-suspended in 10 $\mathrm{ml}$ ofRPMI 1640 supplement with 10\% FBS medium to obtain a single cell suspension. Based on optimization experiments, melanoma cells were seeded at a final count of $4 \times 10^{4}$ cells/200 $\mu$ l/well in flat-bottomed 96-well micro plates and were incubated at $37{ }^{\circ} \mathrm{C}$ in a humidified atmosphere containing $5 \% \mathrm{CO}_{2}$ for 24 h. Cells were treated with $6.25,12.5,25,50$ and $100 \mu \mathrm{g} / \mathrm{ml}$ of the plant extracts prepared in the same media as described previously. Proper control experiments were also performed, including human fibroblast cell lines as normal cells. Melanoma cell lines were treated with doxorubicin as a positive control, while untreated cells were considered as a negative control.

Triplicate preparations of each treatment group were made and the cultures were then incubated for another $72 \mathrm{~h}$ before measurement of cell viability using 3-(4,5-dimethylthiazol-2-yl)-2,5diphenyltetrazolium bromide MTT. PBS $(20 \mu \mathrm{l})$ containing $5 \mathrm{mg} / \mathrm{ml}$ MTT was added. After incubation for $3 \mathrm{~h}$ at $37^{\circ} \mathrm{C}$, the supernatant was discarded and the formazan blue crystals formed in the cells was dissolved in $200 \mu$ dimethyl sulfoxide (DMSO). The optical density at $570 \mathrm{~nm}$ was measured (BioteK, USA) and compared with that of the control (untreated). $I_{50}$, the concentration at which $50 \%$ of cell viability was inhibited, was then calculated.

\section{Statistical analysis}

Data collected were analysed and expressed as mean $\pm \operatorname{SD}(n=3)$. Statistical analysis was carried out usingone-way ANOVA in Prism (GraphPad, USA). P values less than 0.05 were considered to be significant.

\section{RESULTS}

The MTT assay results showed that there were no significant cytotoxic effects of the tested extracts on the proliferation of A375.S2 melanoma cells within the concentration ranges used in these experiments. Similar results also were obtained when they were tested against the normal fibrocytes cell line. On the other hand, Sage, Chamomile, Rhubarb, and Licorice extracts inhibited the melanotic WM1361A proliferation in a dose-dependent manner revealing an $\mathrm{IC}_{50}$ of $20.6,25.2,17.8,35.2 \mu \mathrm{g} / \mathrm{ml}$, respectively (Figure 1). The degree of cellular inhibition increased with increasing the concentration of the plant extracts with a high correlation coefficient (Figure 1). However, both Dwarf Elder and Fenugreek extracts did not 


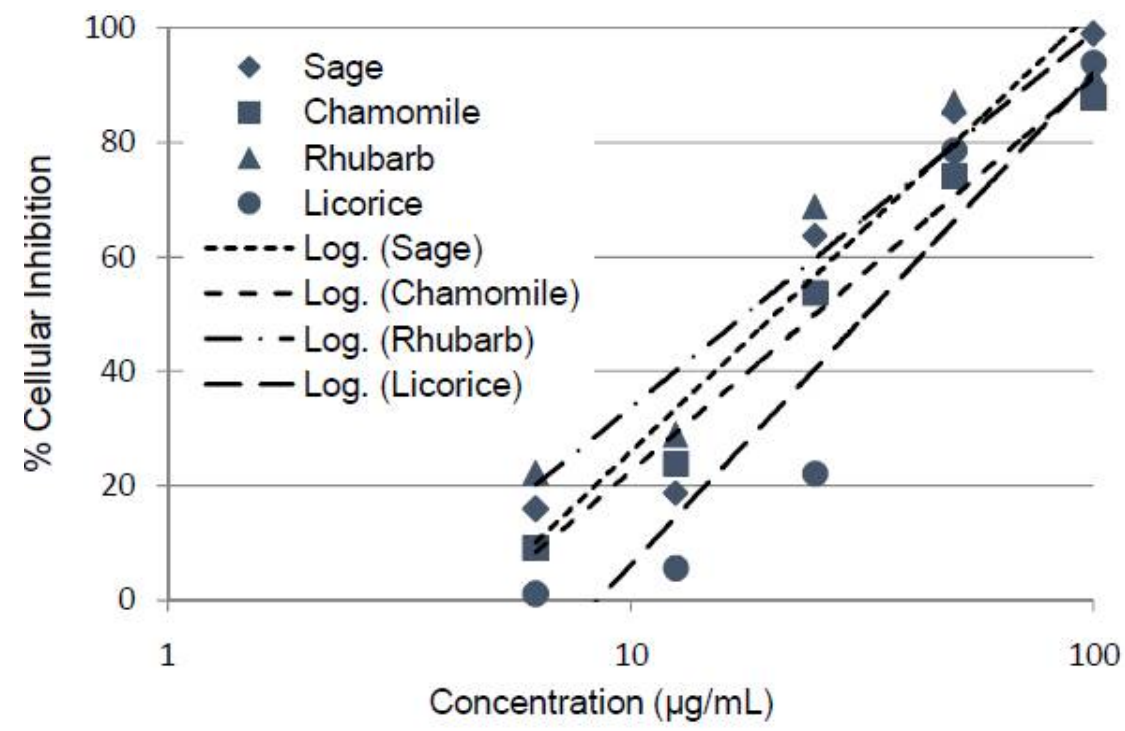

exhibit any significant cytotoxic activity for both melanoma cell lines. Doxorubicin used as positive standard inhibited bothWM1361A and A375.S2 cell lines in a dose dependent manner with an $\mathrm{IC}_{50}$ of 3.5 and $4.7 \mu \mathrm{g} / \mathrm{ml}$ respectively

\section{DISCUSSION}

This study has shown that the extracts of Sage, Chamomile, Rhubarb, and Licorice have inhibitory potential against the melanotic WM1361A proliferation in a dose-dependent manner with the degree of cellular inhibition increasing with increased concentration of the extracts.

Melanotic WM1361A melanoma cell line is characterized with high tyrosinase expression [27] which catalyzes the key step in melanoma synthesis and hence the presence of tyrosinase facilitates the melanin accumulation in these cells. In recent years, several naturally occurring tyrosinase inhibitors which belonged to several chemical classes like phenols, flavanols, terpenes, steroids, flavonoids, alkaloids coumarins, stilbenes, tetra ketones, and many other secondary metabolites have been identified. Many of them have been used in skin whitening, as anti-ageing compounds and in cancer managements [28]. As many tyrosinase inhibitors have shown anti-proliferative activities against melanoma skin cancer cell lines, the inhibitory effects of these plant extracts against melanotic WM1361A can be attributed, at least in part, to the tyrosinase inhibitory activity. Earlier studies have shown that triterpenesaponins present in Glycyrrhiza glabra L. (Licorice) possess anti-inflammatory, anti-allergic and antitumor activities [29, 30]. In addition, the main ingredients of licorice extracts like glycyrrhizin and glycyrrhetinic acid have been shown to modulate melanogenesis in B16 melanoma cell, and tyrosinase inhibition activity has been shown in skin whitening [22]. Anthraquinones, the major active ingredients isolated from of Rhubarb rhizome, are known as tyrosinase enzyme inhibitors[31].

Flavonoids (e.g., apigenin) were described to be the main phytochemical responsible for anticancer activity of chamomile. These have promising effect against skin, prostate, breast and ovarian cancers [32, 33]. Moreover, many of these flavonoids were reported to potentially inhibit the tyrosinase enzyme [28] which can also explain the chamomile effects on the tyrosinase expressing human melanoma cell line WM1361Aunlike A375.S2 cell line where the plant extracts showed no cytotoxic activity. Other compounds associated with cytotoxic activities present in some of the plants are phenols, flavonoids, and terpenoids as the main available secondary metabolites Salvia species [34, 35].

\section{CONCLUSION}

The data obtained in this study suggest that the methanol extracts of $G$. glabra (Licorice), $M$. chamomilla (Chamomile), S. triloba (Sage) and $R$. palmatum (Rhubarb) have potent antiproliferative activity against WM1361A cell line; a representative human melanotic melanocyte tumor cell line. These new insights into the anticancer activity of these plants make them potential source of lead compounds for the development of new, safe and cost effective treatments for skin diseases ranging from rashes to dreadful skin cancer melanoma. Moreover, new natural tryosinase inhibitors from these 
plants can be introduced into natural skin whiting formulations.

\section{DECLARATIONS}

\section{Acknowledgments}

The authors wish to thank the Deanships of Academic Research (DAR) at Al-Balqa Applied University and the University of Jordan for the financial support for this work.

\section{Conflict of interest}

No conflict of interest associated with this work.

\section{Contribution of authors}

The authors declare that this work was done by the authors named in this article and all liabilities pertaining to claims relating to the content of this article will be borne by them.

\section{REFERENCES}

1. Oran S, Al-Eisawi D .Check list of medicinal plants in Jordan. Dirasat Med BiolSci1998; 25: 84-111.

2. Nickavar B, Kamalinejad $M$, Izadpanah $H$. In vitro free radical scavenging activity of five Salvia species. Pak J Pharm Sci2007; 20:291-294.

3. Keshavarz M, Bidmeshkipour A, Mostafavi A, Mansouri K, Mohamadi-Motlagh H. Anti-tumor activity of Salvia officinalis is due to its anti-angiogenic, anti-migratory and anti-proliferative effects. Cell J 2011; 12:477-82.

4. Rami K, Li Z. Antimicrobial activity of essential oil of Salvia officinalis L. collected in Syria. Afr J Biotech 2011; 10:8397-8402.

5. Stanojevic D, Comic L, Stefanovic O, Solujic-Sukdolak S. In vitro synergistic antibacterial activity of Salvia officinalis and some preservatives. Arch BiolSciBelgrad 2010; 62:175-83.

6. Fraihat A, Khalil M, Bustanji Y. Bioactivity of Rosemary and Sage against Measles. Int J Sci Basic Appl Res 2015; 24:222-233

7. Ibrahim A, Aqel A. Effect of salvia trilobaL.f.extracts on neoplastic cell lines. Jordan J BiolSci 2010; 3:69-76.

8. Al-KalaldehJ,Abu-Dahab R, AfifiF. Volatile oil composition and antiproliferative activity of Laurusnobilis, Origanum syriacum, Origanum vulgare, and Salvia triloba against human breast adenocarcinoma cells .Nutr Res2010; 30: 271-278.

9. Srivastavaa JK, Pandeya M, Gupta S. Chamomile, a novel and selective COX-2 inhibitor with antiinflammatory activity. Life Sci 2009; 85: 663-669.

10. Hoermann HP, Korting HC. Evidence for the efficacy and safety of topical herbal drugs in dermatology: part 1: anti-inflammatory agents. Phytomedicine 1994; 1: 161-171

11. Srivastava JK, Gupta S. Antiproliferative and apoptotic effects of chamomile extract in various human cancer cells. J Agric Food Chem 2007; 55(23): 9470-9478.

12. Sinha S, Gupta AK, Bhatt K. Uptake and translocation of metals in fenugreek grown on soil amended with tannery sludge: Involvement of antioxidants Ecotoxicol Environ Saf2007: 67:267-277.

13. Amin A, Alkaabi A, Al-Falasi S, Daoud SA. Chemopreventive activities of Trigonella foenumgraecum (Fenugreek) against breast cancer. Cell Biollnt2005; 29:687-694.
14. Bin-Hafeez B, Haque R, Parvez S, Pandey S, Sayeed I, Raisuddin S. Imunomodulatory effects of fenugreek (Trigonella foenum-graecum L.) extract in mice. IntImmunopharmacol 2003; 3:257-265.

15. Vijayakumar $M$, Singh $S$, Chhipa $R$, Bhat $M$. The hypoglycaemic activity of fenugreek seed extract is mediated through the stimulation of an insulin signalling pathway. Br J Pharmacol 2005; 146:41-48.

16. Wang L,BaoD, Changli Y, Jingyan W, Ziming S, Yuhua $Z$. Ultrasonic extraction and separation of anthraquinones from Rheum palmatum. Ultrason Sonochem 2007; 15:738-746.

17. WangJ, ZhaoH, KongW, JinC, ZhaoY, QuY, XiaoX. Microcaloremetric assay on the antimicrobial property of five hydroxyanthraquinone derivatives in rhubarb(Rheum palmatum L.) to Bifidob bacterium adolescentis. Phytomedicine2010;17:684-689

18. He Z, Zhou R, He M, Lau CB, Yue G, GeW,But P. Antiangiogenic effect and mechanism of rhein from RhizomaRhei. Phytomedicine 2011; 18(6):470-478.

19. Khazaeli $P$, Goldoozian R, Sharififar $F$. An evaluation of extracts of five traditional medicinal plants from Iran on the inhibition of mushroom tyrosinase activity and scavenging of free radicals. Int $J$ CosmetSci2009; 31:375-381.

20. Sitohy MZ, el-Massry RA, el-Saadany SS, Labib, SM.Metabolic effects of licorice roots (Glycyrrhizaglabra) on lipid distribution pattern, liver and renal functions of albino rats, Nahrung 1991; 35(8):799-806.

21. Soma R, Keda M, Mourisa T. Effect of Glycyrrhizin on cortisol metabolism in human, EndocrRegul1994; 28(1):31-34

22. Abe $H$, Ohya $N$, Yamamoto $K$, Shibuya $F$, Arichi $S$, Odashima S. Effects of glycyrrhizin and glycyrrhetinic acid on growth and melanogenesis in cultured B16 melanoma cells. Eur J Cancer ClinOncol1987; 23:1549-1555.

23. Ahmadini A, Fereidoni M, Semnanian M, Saremi $S$. Antinociceptive and anti-inflammatory effects of Sambucus ebulus rhizome extract in rats. $J$ Ethnopharmacol 1998; 61(3):229

24. Ebrahimzadeh $M$, Mahmoudi $M$, Karami $M$, Saeedi $A$, Ahmadi H, Salimi E. Seperation of active and toxic portions in Sambucus ebulus. Pak J Biol Sci 2007; 10:4171-4173.

25. Zahmanov G, Alipieva $K$, Denev $P$, Todorov D, Hinkov $A$, Shishkov S, Simova S, Georgiev M. Flavonoid glycosides profiling in dwarf elder fruits (Sambucus ebulus L.) and evaluation of their antioxidant and anti-herpes simplex activities. Ind Crops Prod 2015; 63: $58-64$.

26. Jordan Cancer Registry. Cancer Incidence in Jordan2009 Report. Amman (JO): Ministry of Health 2010: 44-47.

27. Pope JH, Morrison L, Moss DJ, Parsons PG, Mary SR. Human malignant melanoma cell lines. Pathology 1979; 11: 191-195.

28. Jennifer C, Stephie CM, Abhishri SB, Shalini BU. A Review on skin whitening property of plant extracts. Int J Pharm Bio Sci 2012; 3: 332-347.

29. Finney $R$, Tarknoy $A$. The pharmacological properties of glycyrrhetinic acid hydrogen succinate. J Pharm Pharmacol 1960; 12: 49-58.

30. Tanaka S, Uno C, Akimoto M, Tabata M, Honda C, Kamisako W. Anti-allergic effect of broyonolic acid from luffa cylindrical cell suspension cultures. Planta Med1991; 57: 527-530

31. Rashid S, Kaloo ZA, Singh S, Bashir I. Medicinal importance of Genus Rheum -A review. Int J Adv Res 2014; 2:261-267.

32. Way TD, Kao MC, Lin JK. Apigenin induces apoptosis through proteasomal degradation of HER2/neu in HER2/neu-over expressing breast cancer cells via the phosphatidylinositol 3-kinase/Akt-dependent pathway. J Biol Chem 2004; 279(6):4479-4489. 
33. Shukla S, Mishra A, Fu P, MacLennan GT, Resnick MI, Gupta S. Up-regulation of insulin-like growth factor binding protein-3 by apigenin leads to growth inhibition and apoptosis of 22Rv1 xenograft in athymic nude mice. FASEB J 2005; 19(14):20422044.

34. Süntar I, Akkol EK, Senol FS, Keles H. Investigating wound healing, tyrosinase inhibitory and antioxidant activities of the ethanol extracts of Salvia cryptantha and Salvia cyanescens using in vivo and in vitro experimental models. J Ethnopharmacol2011; 135: 71-77.

35. Topçu G. Bioactive triterpenoids from Salvia species. Nat Prod J 2006; 69: 482-487 